\title{
Exploring the Chemical Space of Benzothiazole-Based DNA Gyrase B Inhibitors
}

\author{
pÿSkok, \}iga
}

2020-12-10

pÿSkok , \}, Baranoková , M , Benek , O , Cruz , C D , Tammela , P , Tomaai , T , Zidar , N , pÿMaai , L P , Zega , A , Stevenson , C E M , Mundy , J E A , Lawson , D M , Maxwell , A , pÿKikelj , D \& Ilaa , J 2020 , ' Exploring the Chemical Space of Benzothiazole-Based DNA

Gyrase B Inhibitors ' , ACS Medicinal Chemistry Letters , vol. 11 , no. 12 , pp. 2433-2440 . https://doi.org/10.1021/ac

http://hdl.handle.net/10138/335330

https://doi.org/10.1021/acsmedchemlett.0c00416

acceptedVersion

Downloaded from Helda, University of Helsinki institutional repository.

This is an electronic reprint of the original article.

This reprint may differ from the original in pagination and typographic detail.

Please cite the original version. 


\title{
Exploring the Chemical Space of Benzothiazole-Based DNA Gyrase B Inhibitors
}

\author{
Žiga Skok, ${ }^{\mathrm{a}}+$ Michaela Barančoková, ${ }^{\mathrm{a}}$ Ondřej Benek, ${ }^{\mathrm{b}}$ Cristina Durante Cruz, ${ }^{\mathrm{c}}$ Päivi Tammela, ${ }^{\mathrm{c}}$ \\ Tihomir Tomašič, ${ }^{a}$ Nace Zidar, ${ }^{a}$ Lucija Peterlin Mašič, ${ }^{a}$ Anamarija Zega, ${ }^{a}$ Clare E.M. Stevenson, ${ }^{d}$ \\ Julia E. A. Mundy, ${ }^{d}$ David M. Lawson, ${ }^{d}$ Anthony Maxwell, ${ }^{d}$ Danijel Kikelj, ${ }^{\text {a }}$ and Janez Ilaš ${ }^{* a}$ \\ ${ }^{a}$ University of Ljubljana, Faculty of Pharmacy, Aškerčeva cesta 7, 1000 Ljubljana, Slovenia; ${ }^{b}$ University of Hradec \\ Králové, Faculty of Science, Department of Chemistry, Rokitanského 62, 500 o3 Hradec Králové, Czech Republic; ${ }^{\mathrm{c}}$ \\ Centre for Drug Research, Division of Pharmaceutical Biosciences, Faculty of Pharmacy, University of Helsinki, P.O. \\ Box 56 (Viikinkaari 5 E), Helsinki FI-ooo14, Finland. ${ }^{d}$ Department of Biological Chemistry, John Innes Centre, Nor- \\ wich Research Park, Norwich NR4 7UH, UK.
}

\begin{abstract}
We designed and synthesized a series of inhibitors of the bacterial enzymes DNA gyrase and DNA topoisomerase IV, based on our recently published benzothiazole-based inhibitor bearing an oxalyl moiety. To improve the antibacterial activity and retain potent enzymatic activity, we systematically explored the chemical space. Several strategies of modification were followed: varying substituents on the pyrrole carboxamide moiety, alteration of the central scaffold, including variation of substitution position and, most importantly, modification of the oxalyl moiety. Compounds with acidic, basic and neutral properties were synthesized. To understand the mechanism of action and binding mode, we have obtained a crystal structure of compound 16a, bearing a primary amino group, in complex with the N-terminal domain of E. coli gyrase B (24 kDa) (PDB: 6YD9). Compound 15a, with a low molecular weight of 383 Da, potent inhibitory activity on $E$. coli gyrase $\left(\mathrm{IC}_{50}=9.5 \mathrm{nM}\right)$, potent antibacterial activity on $E$. faecalis $(\mathrm{MIC}=3.13 \mu \mathrm{M})$ and efflux impaired $E$. coli strain $(\mathrm{MIC}=0.78 \mu \mathrm{M}$ ), is an important contribution for the development of novel gyrase and topoisomerase IV inhibitors in Gram-negative bacteria.
\end{abstract}

KEYWORDS: DNA gyrase; topoisomerase IV; GyrB; ParE; antibacterial; benzothiazole;

The treatment of infections has advanced beyond recognition since the first discoveries of antimicrobial compounds. Widespread distribution, low price and high safety profile have established antimicrobial drugs as a cornerstone of modern medicine. However, due to rising resistance issues, the efficacy of existing infection treatments is rapidly decreasing. The dearth of new anti-infectives introduced to the market over recent years, and no discovery of novel classes, has deepened the problem. ${ }^{1-4}$ Antimicrobial resistance is now a serious global health concern; infections that are currently readily treatable could become untreatable in the near future. 5

DNA topoisomerases are enzymes that alter DNA topology, being involved in important biological processes in the cell (replication, transcription, chromosome condensation, etc.). ${ }^{6-11}$ Bacterial DNA gyrase and DNA topoisomerase IV (topo IV) are attractive targets for antibacterial drug discovery due to their well-described structure and mechanism, as well as their absence from eukaryotes. Both enzymes are type II topoisomerases, sharing high functional and structural similarity. They change the topology of DNA by cleaving both strands of the double-helix. Gyrase has the unique function of introducing negative supercoiling ahead of the replication fork, while topo IV is involved in chromosome decatenation. The enzymes consist of two pairs of subunits with different functions, forming heterotetrameric structures: $A_{2} B_{2}$ (gyrase) or $C_{2} E_{2}$ (topo IV). The main role of the GyrA and ParC subunits is to release torsional stress by breaking and rejoining strands of the DNA molecule. GyrB and ParE contain the ATP-binding site and provide the energy required for the enzyme function by ATP hydrolysis. ${ }^{12-13}$

DNA gyrase inhibitors can influence the enzyme action at different levels. ${ }^{14}$ Inhibition of the GyrA subunit can cause stabilization of the DNA-enzyme complex, and thus broken strands of DNA cannot be re-joined. GyrA inhibitors, socalled gyrase poisons, are represented by fluoroquinolones, which are widely in clinical use, although struggling with side effects and growing resistance concerns. ${ }^{6}$ These problems have encouraged further research on inhibitors with different mechanisms of action. GyrB inhibitors are not currently in clinical use; novobiocin, was withdrawn from the market in the 1960 s due to significant side effects. Since then, no other GyrB inhibitor has passed clinical trials. ${ }^{7}$ Low crossresistance between potential GyrB inhibitors and fluoroquinolones is a promising and motivating factor for further research. Novel gyrase inhibitors based on various chemical structures were discovered in recent years. ${ }^{8}$

Our research group has recently published several articles focusing on ATP-competitive inhibitors of the DNA gyrase B protein $(\mathrm{GyrB}) .^{15-17}$ The compounds share a common pyrrole- 
2-carboxamide moiety, originating from marine alkaloids such as oroidin. ${ }^{18}$ Compounds are potent inhibitors of gyrase; however they lack potent antimicrobial activity. The mode of action for this series of compounds was confirmed by solving the crystal structure of complex of $E$. coli GyrB with a benzothiazole-type inhibitor $\mathbf{1}\left(\mathrm{PDB}{ }_{5} \mathbf{L} 3 \mathbf{J}\right) \cdot{ }^{15}$

Our goal was to explore the chemical space of pyrrolebenzothiazole GyrB inhibitors by selecting those that retain potent enzyme inhibition whilst optimizing their physicochemical properties. Several strategies of modification illustrated in Fig. 1, were followed: alteration of the pyrrole carboxamide moiety, alteration of the central scaffold, including variation of the substitution position, and most importantly modification of the oxalyl moiety.

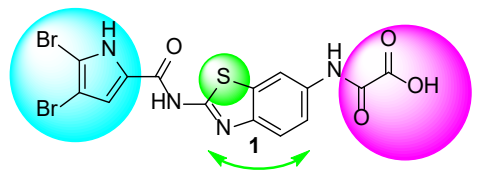

Fig. 1. Structure of previously-discovered compound 1 (PDB 5L3J) with highlighted positions selected for structure modifications.

The 4,5-dibromo- $1 H$-pyrrole-2-carboxamide interacting with the protein through hydrogen bonding interactions of the pyrrole nitrogen and adjacent carbonyl with Asp73, either directly or via a network of hydrogen bonds involving conserved water molecule, respectively does not permit substantial changes. Modification to 3,4-dichloro-5-methyl${ }_{1} H$-pyrrole-2-carboxamide has several potential beneficial properties. The key role of the pyrrole nitrogen and nonsubstituted carboxamide moiety remains unchanged. Smaller chlorine atoms (compared to bromine) are likely to fit better into the E. coli topo IV hydrophobic pocket and the Staphylococcus aureus gyrase hydrophobic pocket, which has a smaller volume than the $E$. coli gyrase hydrophobic pocket. ${ }^{19}$ The 3,4-dichloro-5-methyl- $1 H$-pyrrole-carboxamide moiety is present in the natural antibiotics kibdelomycin ${ }^{20-22}$ and amycolamicin ${ }^{23,24}$ and was used in the Astra Zeneca pyrrolamide series of gyrase B inhibitors. ${ }^{2-27}$

To explore the influence of the central scaffold we interchanged the substituents on positions 2 and 6 of benzothiazole, resulting in interchanging the position of the benzene ring and thiazole ring of the benzothiazole moiety ${ }^{28}$ in the binding site and its $\pi$-cation interactions with Arg76, as well as influencing the acidity of pyrrole amide proton. An obvious bioisosteric approach was the replacement of the ring sulphur (benzothiazole) with nitrogen to give a benzimidazole central scaffold. Indeed, benzimidazole-ureas were presented as potent dual inhibitors of bacterial topoisomerases in a recent study by Vertex Pharmaceuticals. ${ }^{29}$ In this manner, crucial cation- $\pi$ interactions between the core benzene ring and Arg76 and the Glu5o-Arg76 salt bridge interactions were preserved. Additional interactions might have been introduced by enlarging the central scaffold, but we did not plan to increase the scaffold MW.

The focus of the optimisation strategy was the replacement of the oxalyl moiety, which is likely too acidic and might impair permeation into bacteria and thus diminish antimicrobial activity. As confirmed by the crystal structure of $\mathbf{1}$, the oxalyl moiety extending out of the binding pocket and making only a single direct hydrogen bond to the protein, via the carbonyl group to Arg136, can be replaced without loss of inhibitory activity. We systematically changed the acidic oxalyl moiety to i) a neutral small aliphatic acyl moiety (acetamide group) ii) a neutral aromatic moiety (isonicotinamide moiety) iii) a neutral polar group with $\mathrm{H}$-bond donor/acceptor potential (urea derivative) iv) and an aliphatic primary amino group (derivatives of glycine and beta alanine).

Synthesis of benzimidazole compounds, illustrated in Scheme 1, starts with coupling of 6-nitro- $1 H_{-}$ benzo[ $d]$ imidazol-2-amine with 2,2,2-trichloro-1- $\left(4,5^{-}\right.$ dibromo-1 $H$-pyrrol-2-yl)ethan-1-one and a weak base in DMF. The nitro group of intermediate $\mathbf{2}$ is reduced using tin(II) chloride dihydrate to give amino-derivative 3, further acylated with respective acyl chloride to obtain esters $\mathbf{4 a - b}$. Corresponding carboxylic acids $\mathbf{5} \mathbf{a}-\mathbf{b}$ were obtained by alkaline hydrolysis.

Synthesis of benzothiazole-based compounds is illustrated in Scheme 2. Acylation of 6-nitro-benzo[d]thiazol-2-amine (6) with ethyl oxalyl chloride / methyl malonyl chloride / acetyl chloride gives intermediates $\mathbf{7 a}, \mathbf{7} \mathbf{b}$ and $\mathbf{7 c}$ respectively.

\section{Scheme 1. Reagents and conditions}
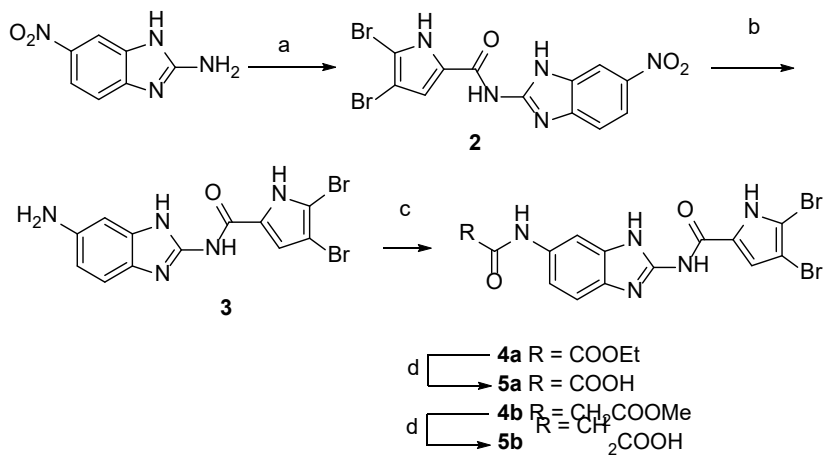

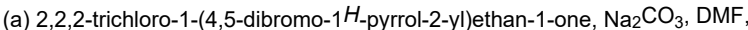
$80{ }^{\circ} \mathrm{C}, 16 \mathrm{~h}$; (b) $\mathrm{SnCl}_{2}{ }^{\circ} \mathrm{H}_{2} \mathrm{O}$, EtOH, reflux, $12 \mathrm{~h}$; (c) ethyl oxalyl chloride (for $4 \mathrm{a}$ ) or methyl malonyl chloride (for $\mathbf{4 b}$ ), Et ${ }_{3} \mathrm{~N}, 1,4$-dioxane, rt, $12 \mathrm{~h}$; (d) $1 \mathrm{M} \mathrm{NaOH}$, 1,4-dioxane, rt, $16 \mathrm{~h}$

\section{Scheme 2. Reagents and conditions}




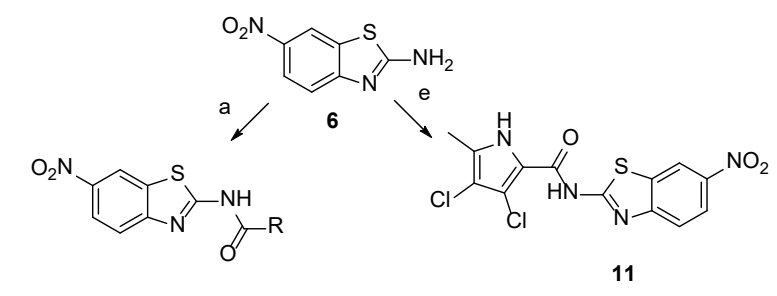

7a $\mathrm{R}=\mathrm{COOEt}$

7b $\mathrm{R}=\mathrm{CH}_{2} \mathrm{COOMe}$

7c $\mathrm{R}=\mathrm{Me}$

$\downarrow$
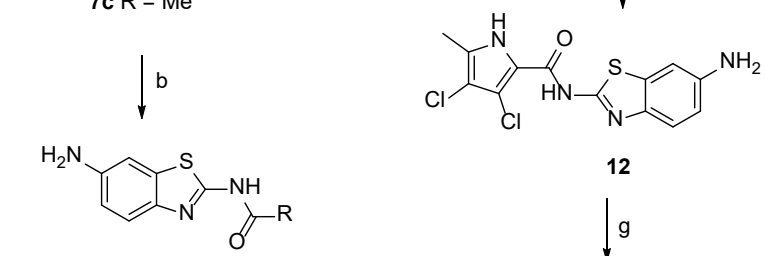

8a $\mathrm{R}=\mathrm{COOEt}$

8b $\mathrm{R}=\mathrm{CH}_{2} \mathrm{COOMe}$

$8 \mathrm{c} R=\mathrm{Me}$
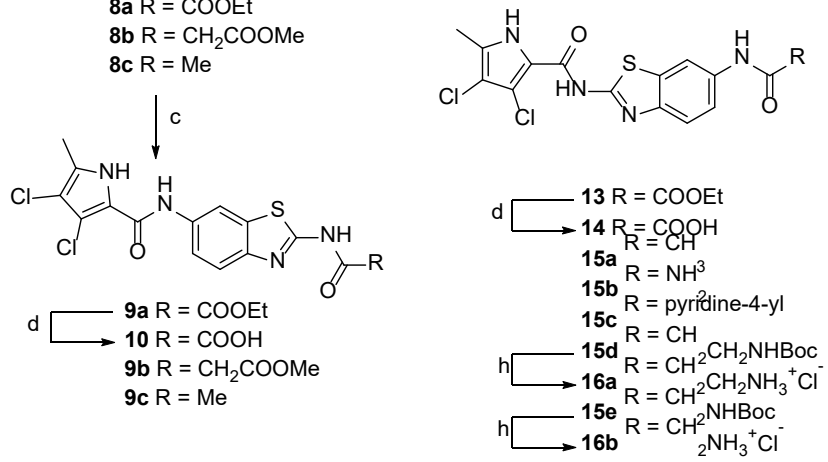

(a) corresponding acyl chloride, Et ${ }_{3} \mathrm{~N}, 1$,4-dioxane, rt, 4 h; (b) $\mathrm{H}_{2}, 10 \% \mathrm{Pd} / \mathrm{C}$, $\mathrm{EtOH}$ (for $\mathbf{8 a}$ and $\mathbf{8 c}$ ) or $\mathrm{MeOH}$ (for $\mathbf{8 b}$ ), rt, 24 h; (c) 3,4-dichloro-5-methyl-1 $\mathrm{H}^{-}$ pyrrole-2-carbonyl chloride, pyridine, DCM, (d) $1 \mathrm{M} \mathrm{NaOH}, \mathrm{MeOH}, \mathrm{rt}, 24 \mathrm{~h}$, (e)

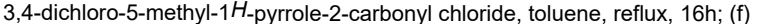
$\mathrm{SnCl}_{2}{ }^{\circ} 2 \mathrm{H}_{2} \mathrm{O}$, EtOH, reflux, $12 \mathrm{~h}$; (g) ethyl oxalyl chloride, $\mathrm{Et}_{3} \mathrm{~N}, 1,4$-dioxane, rt, 8 $\mathrm{h}$ (for the synthesis of 13); (g) $\mathrm{Ac}_{2} \mathrm{O}, \mathrm{Et}_{3} \mathrm{~N}, \mathrm{DCM}, \mathrm{rt}, 2 \mathrm{~h}$ (for the synthesis of 15a); or CDI, DMF, rt, 3h; $\mathrm{NH}_{3}$, rt, $16 \mathrm{~h}$ (for the synthesis of $15 \mathrm{~b}$ ); or nicotinic acid, EDC, $\mathrm{NMM}, \mathrm{HOBt}, \mathrm{DMF}, \mathrm{rt}, 12 \mathrm{~h}$ (for the synthesis of $15 \mathrm{c}$ ); or corresponding Boc-amino acid, EDC, NMM, HOBt, DMF, rt, 12h (for the synthesis of 15d-e); (h) $4 \mathrm{M} \mathrm{HCl}$,

1,4-dioxane, rt, $5 \mathrm{~h}$

Table 1. Inhibitory activity of series I of compounds with benzimidazole central scaffold.

\begin{tabular}{|c|c|c|c|c|c|c|}
\hline & & & $\mathrm{Br}^{\prime}$ & $\stackrel{H}{N}$ & $\begin{array}{l}n=0, R=E t \\
n=1, R=M e \\
n=0, R=H \\
n=1, R=H\end{array}$ & \\
\hline \multirow[b]{2}{*}{ Cmpd } & \multirow[b]{2}{*}{$\mathrm{n}$} & \multirow[b]{2}{*}{$\mathrm{R}$} & \multicolumn{2}{|c|}{$\mathrm{IC}_{50}(\mu \mathrm{M})$ or $\mathrm{RA}(\%)^{\mathrm{a}}$} & \multirow[b]{2}{*}{ S. aureus gyrase } & \multirow[b]{2}{*}{ S. aureus topo IV } \\
\hline & & & E. coli gyrase & E. coli topo IV & & \\
\hline $4 a$ & $\mathrm{o}$ & Et & $4.0 \pm 1.6 \mu \mathrm{M}$ & $100 \%$ & $100 \%$ & $100 \%$ \\
\hline $4 \mathrm{~b}$ & 1 & $\mathrm{Me}$ & $7.0 \pm 3.4 \mu \mathrm{M}$ & $100 \%$ & $100 \%$ & $100 \%$ \\
\hline $5^{a}$ & o & $\mathrm{H}$ & $0.60 \pm 0.32 \mu \mathrm{M}$ & $12 \pm 2 \mu \mathrm{M}$ & $80 \pm 23 \mu \mathrm{M}$ & $31 \pm 1 \mu \mathrm{M}$ \\
\hline $5^{b}$ & 1 & $\mathrm{H}$ & $1.5 \pm 0.2 \mu \mathrm{M}$ & $100 \%$ & $100 \%$ & $100 \%$ \\
\hline $\mathbf{1}$ & & & $0.058 \mu \mathrm{M}$ & $13 \mu \mathrm{M}$ & $>100 \mu \mathrm{M}$ & $10 \mu \mathrm{M}$ \\
\hline novobiocin & & & $0.17 \mu \mathrm{M}$ & $11 \mu \mathrm{M}$ & $0.041 \mu \mathrm{M}$ & $27 \mu \mathrm{M}$ \\
\hline
\end{tabular}

a Residual activity of the enzyme at $10 \mu \mathrm{M}$ concentration of the compound.

The nitro group in position 6 of the benzothiazole was then reduced using hydrogen and palladium catalyst to obtain compounds 8a-c. Coupling with 3,4-dichloro-5-methyl-1 $\mathrm{H}$ pyrrole-2-carboxylic acid (activated in situ with oxalyl chlo- ride) in DCM in the presence of pyridine as base, gave compounds 9a-c. The ethyl oxalyl derivative 9a was further hydrolysed to carboxylic acid 10. Synthesis of the reversed isomers with the pyrrole moiety at position 2 is more demand- 
ing. The coupling of benzothiazole 6 with the pyrrole-2carbonyl chloride moiety was done in refluxing toluene without any base, to obtain intermediate 11. The nitro group is reduced using tin(II) chloride dihydrate to give key amino derivative 12, which was further derivatized. Acylation with oxalyl chloride moiety gave ester 13. The corresponding carboxylic acid $\mathbf{1 4}$ is isolated after hydrolysis with $1 \mathrm{M}$ sodium hydroxide. Reaction of amino derivative 12 with acetic anhydride in the presence of triethylamine in DCM gave target compound 15a. To obtain the urea derivative $15 \mathbf{b}$, aminobenzothiazole 12 was first stirred at RT with CDI in DMF for $3 \mathrm{~h}$ and heated to $50^{\circ} \mathrm{C}$ overnight after addition of ammonia gas. Compounds $15 \mathrm{C}-\mathbf{e}$ were prepared by coupling of 12 with nicotinic acid (15c), Boc- $\beta$-alanine (15d) or Boc-glycine (15e) in the presence of coupling agents EDC, HOBt or NMM, respectively in DMF. The Boc protective group of $15 \mathbf{d}$-e was finally removed with $\mathrm{HCl}$ in dioxane, to obtain $\mathbf{1 6 a - b}$.

Compounds were evaluated in $E$. coli and $S$. aureus gyrase supercoiling assays as well as in E. coli and $S$. aureus topo IV relaxation assays. The results are presented in Tables 1-3 as $\mathrm{IC}_{50}$ values or residual activity (RA) of the enzyme in a concentration of $10 \mu \mathrm{M}$ of the inhibitor.

The benzimidazole-based series was shown to be only weakly active (Table 1), with inhibitory activity against E. coli gyrase in the micromolar range. Carboxylic acids $\mathbf{5} \mathbf{a}-\mathbf{b}$ were approximately 10-fold more active than the corresponding esters $4 \mathbf{a}-\mathbf{b}$, due to possible ionic interactions additional to hydrogen bonds with Arg136. The most potent compound 5a $\left(\mathrm{IC}_{50}=0.60 \mu \mathrm{M}\right)$ showed weak activity against $S$. aureus gyrase and $E$. coli/S. aureus topo IV). Direct comparison of benzothiazole $\mathbf{1}$ with benzimidazole 5 a shows that replacement of sulphur with nitrogen resulted in 10-fold lower enzymatic inhibition against E. coli gyrase. Poor activity results and poor solubility of benzimidazoles pointed us back to the benzothiazole central scaffold, and the benzimidazole series was not further extended. Replacement of 4,5-dibromo- $1 \mathrm{H}$ pyrrole with 3,4-dichloro-5-methyl-1 $H$-pyrrole indeed resulted in good inhibitory activity against $E$. coli gyrase but even more importantly it introduced good inhibitory activity against $E$. coli topo IV (14: $\mathrm{IC}_{50}$ topo IV $\left.=75 \mathrm{nM}\right)$ and potent inhibitory activity against $S$. aureus gyrase and topo IV, which was completely absent in the case of the dibromo analogue 1. When comparing compounds with the pyrrole attached to position 2 (compound 14) to a regioisomer with the pyrrole attached to position 6 (compound 10), the inhibitory activity on $E$. coli gyrase is favourable for compound 10 and even more favourable regarding $E$. coli topo IV inhibitory activity as well $S$. aureus gyrase and topo IV. Overall, compound $\mathbf{1 4}$ has superior enzymatic activity against all four tested enzymes compared to novobiocin. Benzothiazole with 3,4-dichloro-5-methyl- $1 H$-pyrrole on position 2 was thus selected to explore the possible replacements of the unfavourable oxalyl moiety. The results of the E. coli gyrase inhibitory activity assays reveal that the anionic centre is not required for potent inhibitory activity. Compounds with the acetyl moiety, the urea derivative and the glycine derivative with a free primary amino group all possess $E$. coli gyrase inhibitory activity in the low nanomolar range (10-25 nM). Having an aromatic moiety (15c) pointed to the water environment (and possibly having $\pi$-cationic interactions with Arg136) is clearly not optimal for this series of compounds, although such an approach was successful in tricyclic inhibi-

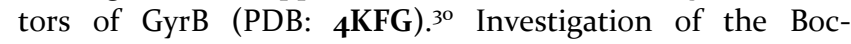
protected amino acid derivatives $15 \mathrm{~d}$ and $16 \mathbf{a}$ reveals that the bulky lipophilic moiety can have favourable binding to $E$. coli GyrB. Although this might seem contradictory, it is known from thermodynamic evaluations that the binding of compound with "unfavourable" lipophilic moieties extending into a water environment can be beneficial as more polar/ionized groups can pay a high desolvation penalty, which contributes to net unfavourable binding. ${ }^{31}$ The amino compound 12, lacking the carbonyl group, is a very weak binder, which indicates that a carbonyl moiety is a prerequisite for potent enzyme binding. Acetyl derivative 15a with lowest molecular weight in the series and single digit nanomolar binding with $\mathrm{IC}_{50}=9.5 \mathrm{nM}$ seemed very interesting, therefore regioisomer 9c with a pyrrole attached to position 6 and acetyl to position 2 of benzothiazole was prepared. The trend observed already from previous compounds was the same in this series: the isomer 15 a with pyrrole attached to position 2 of benzothiazole was 7 -fold more potent than regioisomer with pyrrole attached to position 6 .

Table 2 Inhibitory activity of benzothiazole compounds with acidic terminal functional groups.

\begin{tabular}{|c|c|c|c|c|c|c|}
\hline & & & $\stackrel{H}{N}$ & $\begin{array}{l}\mathrm{R}=\mathrm{Et} \\
\mathrm{R}=\mathrm{Me} \\
\mathrm{R}=\mathrm{H}\end{array}$ & & $\begin{array}{l}\text { 13: } R=E t \\
\text { 14: } R=H\end{array}$ \\
\hline \multicolumn{7}{|c|}{$\mathrm{IC}_{50}(\mathrm{nM})$ or RA $(\%) \mathrm{a}$} \\
\hline Cmpd & $\mathrm{n}$ & $\mathrm{R}$ & E. coli gyrase & E. coli topo IV & S. aureus gyrase & S. aureus topo IV \\
\hline $9 \mathbf{a}$ & o & Et & $290 \pm 170 \mathrm{nM}$ & $100 \%$ & $69 \%$ & $100 \%$ \\
\hline $9 b$ & 1 & Me & $200 \pm 180 \mathrm{nM}$ & $100 \%$ & $59 \%$ & $48 \%$ \\
\hline 10 & o & $\mathrm{H}$ & $29 \pm 16 \mathrm{nM}$ & $6400 \pm 3000 \mathrm{nM}$ & $250 \pm 130 \mathrm{nM}$ & $910 \pm 340 \mathrm{nM}$ \\
\hline 13 & o & Et & $48 \pm 12 \mathrm{nM}$ & $100 \%$ & $100 \%$ & $100 \%$ \\
\hline 14 & o & $\mathrm{H}$ & $4.8 \pm 2.1 \mathrm{nM}$ & $75 \pm 28 \mathrm{nM}$ & $38 \pm 16 \mathrm{nM}$ & $290 \pm 180 \mathrm{nM}$ \\
\hline 1 & & & $58 \mathrm{nM}$ & $13000 \mathrm{nM}$ & $>100 \mu \mathrm{M}$ & $10000 \mathrm{nM}$ \\
\hline novobiocin & & & $168 \mathrm{nM}$ & $11000 \mathrm{nM}$ & $41 \mathrm{nM}$ & $27000 \mathrm{nM}$ \\
\hline
\end{tabular}


Table 3. Inhibitory activity of benzothiazole compounds with neutral or basic terminal functional groups.

\begin{tabular}{|c|c|c|c|c|c|}
\hline \multirow{2}{*}{ Cmpd } & \multirow{2}{*}{$\mathrm{R}$} & $\mathrm{Cl}$ & $\mathrm{Cl}^{-}$ & \multicolumn{2}{|c|}{$\begin{array}{l}\text { 15a: } \mathrm{R}=\mathrm{Me} \\
15 \mathrm{~b}: \mathrm{R}=\mathrm{NH}_{2} \\
15 \mathrm{c}: \mathrm{R}=\text { pyridin-4-yl } \\
15 \text { d: } \mathrm{R}=\mathrm{CH}_{2} \mathrm{CH}_{2} \mathrm{NHBoc} \\
15 \mathrm{e}: \mathrm{R}=\mathrm{CH}_{2} \mathrm{NHBoc}^{+} \\
16 \mathrm{a}: \mathrm{R}=\mathrm{CH}_{2} \mathrm{CH}_{2} \mathrm{NH}_{2}{ }^{+} \mathrm{Cl}^{-} \\
16 \mathrm{~b}: \mathrm{R}=\mathrm{CH}_{2} \mathrm{NH}_{2}{ }^{+} \mathrm{Cl}\end{array}$} \\
\hline & & \multicolumn{4}{|c|}{$\mathrm{IC}_{50}(\mathrm{nM})$ or RA $(\%)^{\mathrm{a}}$} \\
\hline 9c & & $66 \pm 8 \mathrm{nM}$ & $100 \%$ & $35400 \mathrm{nM}$ & $100 \%$ \\
\hline 12 & & $16000 \pm 4$ ooo $\mathrm{nM}$ & $100 \%$ & & $100 \%$ \\
\hline $15 a$ & $-\mathrm{CH}_{3}$ & $9.5 \pm 2.5 \mathrm{nM}$ & $4600 \pm 100 \mathrm{nM}$ & $400 \pm 120 \mathrm{nM}$ & $1600 \pm 300 \mathrm{nM}$ \\
\hline $15 b$ & $-\mathrm{NH}_{2}$ & $26 \pm 8 \mathrm{nM}$ & $5200 \pm 2700 \mathrm{nM}$ & $1300 \pm 600 \mathrm{nM}$ & $5800 \pm 3100 \mathrm{nM}$ \\
\hline $16 a$ & $-\mathrm{CH}_{2} \mathrm{CH}_{2} \mathrm{NH}_{3}{ }^{+} \mathrm{Cl}^{-}$ & $110 \pm 50 \mathrm{nM}$ & $10000 \pm 2000 \mathrm{nM}$ & $1500 \pm 600 \mathrm{nM}$ & $290 \pm 180 \mathrm{nM}$ \\
\hline $16 b$ & $-\mathrm{CH}_{2} \mathrm{NH}_{3}{ }^{+} \mathrm{Cl}^{-}$ & $280 \pm 10 \mathrm{nM}$ & $100 \%$ & $380 \mathrm{nM}$ & $100 \%$ \\
\hline
\end{tabular}

${ }^{a}$ Residual activity of the enzyme at $10 \mu \mathrm{M}$ concentration of the compound.

To confirm binding to the ATP-pocket of GyrB and to gain insight into molecular interactions, crystallisation of selected ligands with the $24 \mathrm{kDa}$ fragment (N-terminal sub-domain) of $\mathrm{GyrB}$ was attempted. Among crystallization attempts with 15a, 16a and 9c, co-crystals of 16a with E. coli GyrB24 were obtained and the structure was solved to a resolution of 1.60 $\AA$ A (Figure 2). The 3,4-dichloro-5-methyl- $\mathrm{H}$-pyrrole moiety of 16a is bound to the adenine-binding pocket, making a hydrogen bond between the pyrrole NH group and Asp73 side chain, while interaction of the Asp73 side chain and pyrrolamide carbonyl oxygen is bridged by coordinated water molecule (NHCO- $\mathrm{H}_{2} \mathrm{O}$ H-bond distance is $2.61 \AA$ ). Comparison with the GyrB crystal structure of kibdelomycin (PDB: ${ }_{4}$ URM) ${ }^{32}$ and Astra Zeneca's pyrrolamide (PDB: 3 TTZ), ${ }^{33}$ reveals identical interactions of the 3,4-dichloro-5-methyl$1 H$-pyrrole moiety. There is a strong $\pi$-cation interaction (3.28 A) between the aromatic ring and Arg76. The carbonyl moiety of $\beta$-alanine interacts with Arg136 through a H-bond Table 4. Antibacterial activity of selected compounds.
(2.87 $\AA$ ), while the primary amino group of $\beta$-alanine is pointed towards the water environment, making no interactions with the protein. While interactions of the oxalyl moiety of 1 with Arg136 were not apparent (PDB code 5L3J, Resolution: $2.83 \AA$ ), improved resolution now offers clear insight into the binding mode. Hydrogen bonding of Arg136 with the carbonyl oxygen of $\beta$-alanine is evident, thus demonstrating that a carboxylic acid moiety is not prerequisite for binding and explains strong enzymatic inhibitory activity of compounds having a neutral side chain.

Compounds were assayed on 4 wild type bacterial strains to determine their antibacterial activity (E. coli, S. aureus, Enterococcus faecalis, Pseudomonas aeruginosa). Additionally, we included two other E. coli strains, an E. coli strain with impaired outer

\begin{tabular}{|c|c|c|c|c|c|c|}
\hline \multirow[t]{2}{*}{ Cmpd } & \multicolumn{6}{|l|}{$\operatorname{MIC}(\mu \mathrm{M})^{\mathrm{a}}$} \\
\hline & $\begin{array}{l}\text { E. coli (ATCC } \\
\text { 25922) }\end{array}$ & $\begin{array}{c}S . \quad \text { aureus } \\
\text { (ATCC 29213) }\end{array}$ & $\begin{array}{c}E . \quad \text { faecalis } \\
\text { (ATCC 29212) }\end{array}$ & $\begin{array}{l}\text { P. aeruginosa } \\
\text { (ATCC 27853) }\end{array}$ & $\begin{array}{c}E . \\
(J \mathrm{D} 17464)^{\mathrm{b}}\end{array}$ & $\begin{array}{l}E . \\
\left(\mathrm{JW}_{5503}\right)^{\mathrm{c}}\end{array}$ \\
\hline $9 b$ & $>50 \mu \mathrm{M}$ & $>50 \mu \mathrm{M}$ & $>50 \mu \mathrm{M}$ & $>50 \mu \mathrm{M}$ & $>50 \mu \mathrm{M}$ & $1.56 \mu \mathrm{M}$ \\
\hline 13 & $>50 \mu \mathrm{M}$ & $>50 \mu \mathrm{M}$ & $>50 \mu \mathrm{M}$ & $>50 \mu \mathrm{M}$ & $>50 \mu \mathrm{M}$ & $50 \mu \mathrm{M}$ \\
\hline $15 b$ & $>50 \mu \mathrm{M}$ & $>50 \mu \mathrm{M}$ & $>50 \mu \mathrm{M}$ & $>50 \mu \mathrm{M}$ & $>50 \mu \mathrm{M}$ & $1.56 \mu \mathrm{M}$ \\
\hline $15 e$ & $>50 \mu \mathrm{M}$ & $>50 \mu \mathrm{M}$ & $3.13 \mu \mathrm{M}$ & $>50 \mu \mathrm{M}$ & $>50 \mu \mathrm{M}$ & $0.78 \mu \mathrm{M}$ \\
\hline $16 a$ & $>50 \mu \mathrm{M}$ & $>50 \mu \mathrm{M}$ & $12.5 \mu \mathrm{M}$ & $>50 \mu \mathrm{M}$ & $>50 \mu \mathrm{M}$ & $12.5 \mu \mathrm{M}$ \\
\hline $16 b$ & $>50 \mu \mathrm{M}$ & $25 \mu \mathrm{M}$ & $6.25 \mu \mathrm{M}$ & $>50 \mu \mathrm{M}$ & $>50 \mu \mathrm{M}$ & $3.13 \mu \mathrm{M}$ \\
\hline
\end{tabular}


${ }^{a}$ MIC (minimum inhibitory concentration that inhibits the growth of bacteria by $\geq 90 \%$ ) values against $E$. coli and $S$. aureus. ${ }^{\text {b }}$ E. coli strain with impaired outer membrane, $\operatorname{lp} x C$ deletion mutant. ${ }^{c} E$. coli strain with defective efflux pump, tolC deletion mutant.

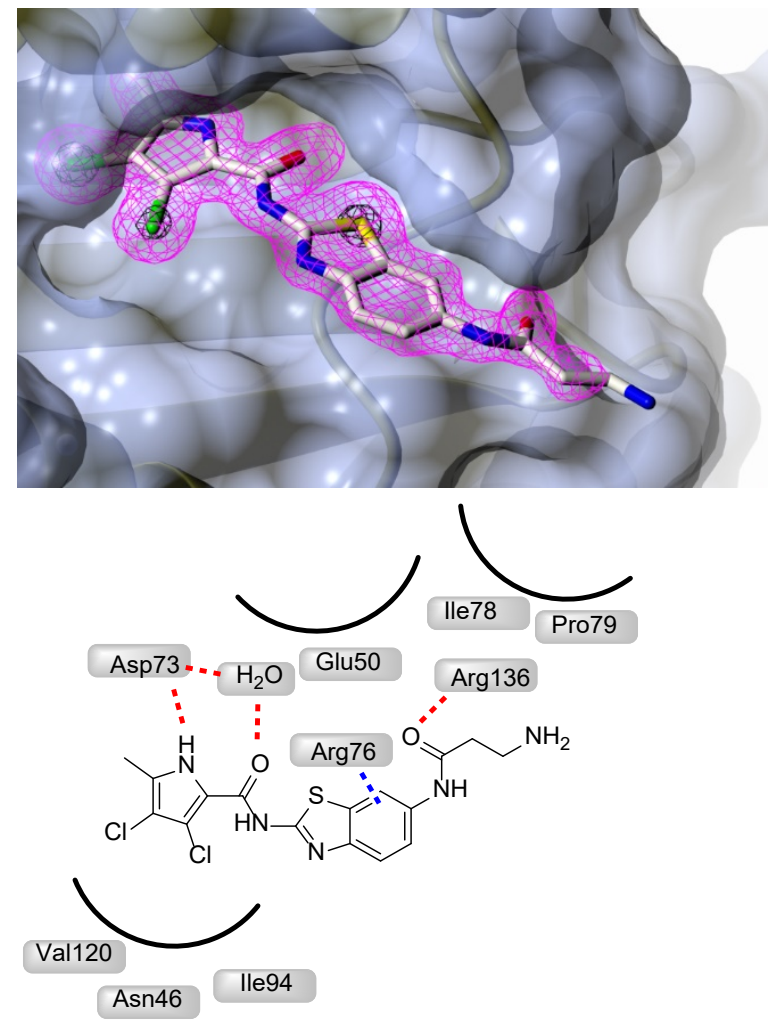

Figure 2. Crystal structure of the complex formed between 16a and E. coli GyrB $24 \mathrm{kDa}$ fragment (PDB: 6YD9). The protein is depicted in cartoon representation covered by a semi-transparent molecular surface. Omit $m F_{\text {obs }}-D F_{\text {calc }}$ positive difference electron density for the ligand at $1.6 \AA$ resolution is depicted at two contour levels: $3 \sigma$ (magenta mesh) and $12 \sigma$ (black mesh), with the latter highlighting the locations of the electron-dense chlorine and sulphur atoms. Shown below are the interactions between amino acid residues with ligand (red line: hydrogen bond, blue line: $\pi$-cation interactions.

membrane (lpxC deletion mutant) and an $E$. coli strain with a defective efflux pump (tolC deletion mutant) to evaluate if weak antibacterial activity on wild type could be due to weak permeability and/or strong efflux. Both benzimidazole and benzothiazole inhibitors with the oxalyl moiety (5a, 1o and 14) were inactive in all bacterial strains (MIC > $50 \mu \mathrm{M})$. Ester derivative $\mathbf{9 b}$ which had good enzymatic inhibitory activity $\left(\mathrm{IC}_{50}=200 \mathrm{nM}\right)$ showed also a good MIC $(1.56 \mu \mathrm{M})$ in the $E$. coli strain with a defective efflux pump, indicating that the ester moiety is beneficial for entry into bacteria; however, such compounds are often the substrates for efflux pumps. Ester derivative $\mathbf{1 3}$ which had very good enzymatic inhibitory activity $\left(\mathrm{IC}_{50}=48 \mathrm{nM}\right)$ showed only weak MIC $(50 \mu \mathrm{M})$ in the E. coli strain with a defective efflux pump.

A significant improvement in MIC value was expected with the compound lacking the acidic oxalyl moiety. Compound 16b, having a glycine moiety with a free primary amino group, was the only compound showing some antibacterial activity on $S$. aureus wild type (MIC $=25 \mu \mathrm{M})$, confirming that good enzymatic inhibitory activity $\left(S\right.$. aureus gyrase $\mathrm{IC}_{50}$ $=380 \mathrm{nM}$ ) with suitable physico-chemical properties is needed for antibacterial activity. When looking at Gram-positive $E$. faecalis, the results were more encouraging, as four compounds showed good antibacterial activity. Both compounds with a free amino group (16a MIC $=12.5 \mu \mathrm{M}$ and 16b MIC = $6.25 \mu \mathrm{M})$ had good antibacterial activity. Boc-protected analogue 15e and compound 15a with an acetyl moiety had even better antibacterial activity with $\mathrm{MIC}=3.13 \mu \mathrm{M}$, which also correlated with enzymatic inhibitory potency. When looking at more challenging Gram-negative $E$. coli and $P$. aeruginosa, the results were less encouraging, as none of the compounds showed antibacterial activity.

Testing on the $E$. coli strain with impaired outer membrane (lpxC deletion mutant), revealed that permeability is not a main issue as tested compounds did not show any antibacterial activity. On the contrary, the compounds were very active when tested on the $E$. coli strain with a defective efflux pump. The most potent compounds were 15e and 15a with submicromolar MIC values $(\mathrm{MIC}=0.78 \mu \mathrm{M})$. Both are neutral molecules with lipophilic moieties (acetyl and Boc). Compounds with free amino group were also potent antibacterial compounds (16a and $\mathbf{1 6 b}$ ) but were not superior to the neutral compounds (15a and 15e). This is somehow contrary to the recent proposal that the introduction of a primary amino group improves entry and causes accumulation in Gram-negative bacteria. ${ }^{34}$ To confirm the mechanism of uptake for the reported compounds (porin pathway or direct diffusion) ${ }^{35}$ additional studies should be performed in order to guide optimization. ${ }^{36,37}$ Urea derivative $\mathbf{1 5} \mathbf{b}$ was also a potent antibacterial compound on the efflux impaired $E$. coli strain (MIC $=1.56 \mu \mathrm{M}$ ), while inactive on all other strains.

In summary, three series of GyrB/ParE inhibitors were designed, synthesized and evaluated in enzymatic and antibacterial assays. Chemical space was thoroughly explored; compounds with acidic, basic and neutral properties were synthesized, possessing very potent inhibitory activity on $E$. coli and/or $S$. aureus gyrase and/or topo IV. The best compounds were active on Gram-positive bacterium $E$. faecalis with the best compound having $\mathrm{MIC}=3.13 \mu \mathrm{M}$. The compounds were inactive on Gram-negative bacteria because they are good substrates for bacterial efflux pumps, but 15a and 15e showed potent antibacterial activity on the efflux impaired $E$. coli strain $(\mathrm{MIC}=0.78 \mu \mathrm{M})$. Compound 15a with low molecular weight $383 \mathrm{Da}$, displayed potent inhibitory activity on $E$. coli gyrase $\left(\mathrm{IC}_{50}=9.5 \mathrm{nM}\right)$, potent antibacterial activity on $E$. faecalis ( $\mathrm{MIC}=3.13 \mu \mathrm{M}$ ) and on the efflux impaired $E$. coli strain $(\mathrm{MIC}=0.78 \mu \mathrm{M})$ and thus makes an important contribution for the development of novel gyrase and topoisomerase inhibitors in Gram-negative bacteria.

\section{ASSOCIATED CONTENT}

\section{Supporting Information}


(i) Experimental conditions for biochemical and microbiological assays, (ii) experimental conditions for cocrystallization, collection, and refinement statistics for compound 16a, (iii) experimental procedures for the synthesis of all the compounds described in this manuscript and (iv) representative analytical data (PDF)

The Supporting Information is available free of charge on the ACS Publications website.

\section{AUTHOR INFORMATION}

\section{Corresponding Author}

* Janez Ilaš, University of Ljubljana, Faculty of Pharmacy, Aškerčeva cesta 7, SI - 1000 Ljubljana, Slovenia, https://orcid.org/oooo-0002-0124-0474, tel: +386-1-4769576; e-mail: janez.ilas@ffa.uni-lj.si

\section{Author Contributions}

The manuscript was written with contributions from all of the authors. $\$$ These authors contributed equally.

\section{Funding Sources}

The work was funded by the EU H2020 ITN-ETN Project INTEGRATE (Project Reference: 642620), EU FP7 Integrated Project MAREX (Project No. FP7-KBBE-2009-3-245137), Academy of Finland (Grant No. 2770o1), and Slovenian Research Agency (Grant No. P1-0208). Work in AM's lab was supported by the Biotechnology and Biosciences Research Council (UK) Institute Strategic Programme Grant BB/Po12523/1, and the Wellcome Trust (Investigator Award $110072 / \mathrm{Z} / 15 / \mathrm{Z})$.

\section{Notes}

The authors declare no competing financial interest.

\section{ACKNOWLEDGMENT}

We acknowledge Diamond Light Source for access to beamline Io4 under proposal MX18565 and Sara Henderson for providing the protein sample.

\section{ABBREVIATIONS}

MIC, minimal inhibitory concentration; RA, residual activity.

\section{REFERENCES}

(1) R.I. Aminov, A brief history of the antibiotic era: lessons learned and challenges for the future. Front Microbiol, 1 (2010) 134.

(2) C. Nathan, O. Cars, Antibiotic resistance--problems, progress, and prospects. N Engl J Med, 371 (2014) 1761-1763.

(3) D.J. Payne, M.N. Gwynn, D.J. Holmes, D.L. Pompliano, Drugs for bad bugs: confronting the challenges of antibacterial discovery. Nat Rev Drug Discov, 6 (2007) 29-40.

(4) L.L. Silver, Challenges of antibacterial discovery. Clin Microbiol Rev, 24 (2011) 71-109.

(5) E.D. Brown, G.D. Wright, Antibacterial drug discovery in the resistance era. Nature, 529 (2016) 336-343.

(6) A.M. Emmerson, A.M. Jones, The quinolones: decades of development and use. J Antimicrob Chemother, 51 Suppl 1 (2003) 13-20.

(7) G.S. Bisacchi, J.I. Manchester, A New-Class AntibacterialAlmost. Lessons in Drug Discovery and Development: A Critical Analysis of More than 50 Years of Effort toward ATPase Inhibi- tors of DNA Gyrase and Topoisomerase IV. ACS Infect Dis, 1 (2015) 4-41.

(8) M. Barančokova, D. Kikelj, J. Ilaš, Recent progress in the discovery and development of DNA gyrase B inhibitors. Future Med Chem, 10 (2018) 1207-1227.

(9) A.D. Bates, A. Maxwell, DNA Topology. Oxford University Press (2005) Oxford.

(10) S.H Chen, N.L. Chan, T.S. Hsieh, New mechanistic and functional insights into DNA topoisomerases. Annu Rev Biochem, 82 (2013) 139-170.

(11) S.M. Vos, E.M. Tretter, B.H. Schmidt, J.M. Berger, All tangled up: how cells direct, manage and exploit topoisomerase function. Nat Rev Mol Cell Biol, 12 (2011) 827-841.

(12) N.G. Bush, K. Evans-Roberts, A. Maxwell, DNA Topoisomerases. EcoSal Plus, 6 (2015).

(13) A.J. Schoeffler, J.M. Berger, DNA topoisomerases: harnessing and constraining energy to govern chromosome topology. Q Rev Biophys, 41 (2008) 41-101.

(14) F. Collin, S. Karkare, A. Maxwell, Exploiting bacterial DNA gyrase as a drug target: current state and perspectives. Appl Microbiol Biotechnol, 92 (2011) 479-497.

(15) M. Gjorgjieva, T. Tomašič, M. Barančokova, S. Katsamakas, J. Ilaš, P. Tammela, L.P. Mašič, D. Kikelj, Discovery of Benzothiazole Scaffold-Based DNA Gyrase B Inhibitors. J Med Chem, 59 (2016) 8941-8954.

(16) N. Zidar, H. Macut, T. Tomašič, M. Brvar, S. Montalvao, P. Tammela, T. Šolmajer, L.P. Mašič, J. Ilaš, D. Kikelj, N-Phenyl-4,5dibromopyrrolamides and $\mathrm{N}$-Phenylindolamides as ATP Competitive DNA Gyrase B Inhibitors: Design, Synthesis, and Evaluation. J Med Chem, 58 (2015) 6179-6194.

(17) N. Zidar, T. Tomasič, H. Macut, A. Sirc, M. Brvar, S. Montalvao, P. Tammela, J. Ilaš, D. Kikelj, New N-phenyl-4,5dibromopyrrolamides and $N$-Phenylindolamides as ATPase inhibitors of DNA gyrase. Eur J Med Chem, 117 (2016) 197-211.

(18) N. Zidar, S. Montalvão, Ž. Hodnik, D.A. Nawrot, A. Žula, J. Ilaš, D. Kikelj, P. Tammela, L. Peterlin Mašič, Antimicrobial Activity of the Marine Alkaloids, Clathrodin and Oroidin, and Their Synthetic Analogues. Mar Drugs, 12 (2014) 940-963.

(19) A. Lamut, Ž. Skok, M. Barančoková, L. J. Gutierrez, C. D. Cruz, P. Tammela, G. Draskovits, P. É. Szili, Á. Nyerges, C. Pál, P. Molek, T. Bratkovič, J. Ilaš, N. Zidar, A. Zega, R. D. Enriz, D. Kikelj, T. Tomašič, Second-generation 4,5,6,7tetrahydrobenzo[d]thiazoles as novel DNA gyrase inhibitors. Future med chem, 12(4) (2020) 277-297.

(20) J.W. Phillips, M.A. Goetz, S.K. Smith, D.L. Zink, J. Polishook, R. Onishi, S. Salowe, J. Wiltsie, J. Allocco, J. Sigmund, K. Dorso, S. Lee, S. Skwish, M. de la Cruz, J. Martin, F. Vicente, O. Genilloud, J. Lu, R.E. Painter, K. Young, K. Overbye, R.G. Donald, S.B. Singh, Discovery of kibdelomycin, a potent new class of bacterial type II topoisomerase inhibitor by chemicalgenetic profiling in Staphylococcus aureus. Chem Biol, 18 (2011) 955-965.

(21) S.B. Singh, M.A. Goetz, S.K. Smith, D.L. Zink, J. Polishook, R. Onishi, S. Salowe, J. Wiltsie, J. Allocco, J. Sigmund, K. Dorso, M. de la Cruz, J. Martin, F. Vicente, O. Genilloud, R.G. Donald, J.W. Phillips, Kibdelomycin A, a congener of kibdelomycin, derivatives and their antibacterial activities. Bioorg Med Chem Lett, 22 (2012) 7127-7130.

(22) J. Lu, S. Patel, N. Sharma, S.M. Soisson, R. Kishii, M. Takei, Y. Fukuda, K.J. Lumb, S.B. Singh, Structures of kibdelomycin bound to Staphylococcus aureus GyrB and ParE showed a novel U-shaped binding mode. ACS Chem Biol, 9 (2014) 20232031.

(23) S. Tohyama, Y. Takahashi, Y. Akamatsu, Biosynthesis of amycolamicin: the biosynthetic origin of a branched alphaaminoethyl moiety in the unusual sugar amycolose. J Antibiot, 63 (2010) 147-149. 
(24) R. Sawa, Y. Takahashi, H. Hashizume, K. Sasaki, Y. Ishizaki, M. Umekita, M. Hatano, H. Abe, T. Watanabe, N. Kinoshita, Y. Homma, C. Hayashi, K. Inoue, S. Ohba, T. Masuda, M. Arakawa, Y. Kobayashi, M. Hamada, M. Igarashi, H. Adachi, Y. Nishimura, Y. Akamatsu, Amycolamicin: a novel broad-spectrum antibiotic inhibiting bacterial topoisomerase. Chemistry, 18 (2012) 15772-15781.

(25) B.A. Sherer, K. Hull, O. Green, G. Basarab, S. Hauck, P. Hill, J.T. Loch, G. Mullen, S. Bist, J. Bryant, A. Boriack-Sjodin, J. Read, N. DeGrace, M. Uria-Nickelsen, R.N. Illingworth, A.E. Eakin, Pyrrolamide DNA gyrase inhibitors: Optimization of antibacterial activity and efficacy. Bioorg Med Chem Lett, 21 (2011) 7416-7420.

(26) A.E. Eakin, O. Green, N. Hales, G.K. Walkup, S. Bist, A. Singh, G. Mullen, J. Bryant, K. Embrey, N. Gao, A. Breeze, D. Timms, B. Andrews, M. Uria-Nickelsen, J. Demeritt, J.T. Loch, 3rd, K. Hull, A. Blodgett, R.N. Illingworth, B. Prince, P.A. Boriack-Sjodin, S. Hauck, L.J. MacPherson, H. Ni, B. Sherer, Pyrrolamide DNA gyrase inhibitors: fragment-based nuclear magnetic resonance screening to identify antibacterial agents. Antimicrob Agents Chemother, 56 (2012) 1240-1246.

(27) M. Uria-Nickelsen, A. Blodgett, H. Kamp, A. Eakin, B. Sherer, O. Green, Novel DNA gyrase inhibitors. J Antimicrob Agents, 41 (2013) 28-35.

(28) S. Cascioferro, B. Parrino, D. Carbone, D. Schillaci, E. Giovannetti, G. Cirrincione, P. Diana, Thiazoles, Their Benzofused Systems, and Thiazolidinone Derivatives: Versatile and Promising Tools to Combat Antibiotic Resistance. J Med Chem, 63 (2020) 7923-7956..

(29) P.S. Charifson, A.-L. Grillot, T.H. Grossman, J.D. Parsons, M. Badia, S. Bellon, D.D. Deininger, J.E. Drumm, C.H. Gross, A. LeTiran, Y. Liao, N. Mani, D.P. Nicolau, E. Perola, S. Ronkin, D. Shannon, L.L. Swenson, Q. Tang, P.R. Tessier, S.-K. Tian, M. Trudeau, T. Wang, Y. Wei, H. Zhang, D. Stamos. Novel DualTargeting Benzimidazole Urea Inhibitors of DNA Gyrase and Topoisomerase IV Possessing Potent Antibacterial Activity: Intelligent Design and Evolution through the Judicious Use of Structure-Guided Design and Structure-Activity Relationships. J Med Chem, 51 (2008) 5243-5263.
(30) L.W. Tari, X. Li, M. Trzoss, D.C. Bensen, Z. Chen, T. Lam, J. Zhang, , S. J. Lee, G. Hough, D. Phillipson, S. Akers-Rodriguez, M. L. Cunningham, B. P. Kwan, K. J. Nelson, A. Castellano, J. B. Locke, V. Brown-Driver, T. M. Murphy, V. S. Ong, C. M Pillar, J. Finn, Tricyclic GyrB/ParE (TriBE) Inhibitors: A New Class of Broad-Spectrum Dual-Targeting Antibacterial Agents. PLoS ONE, 8(12) (2013) e84409.

(31) J. Cramer, S. G. Krimmer, A. Heine, G. Klebe, Paying the Price of Desolvation in Solvent-Exposed Protein Pockets: Impact of Distal Solubilizing Groups on Affinity and Binding Thermodynamics in a Series of Thermolysin Inhibitors. J Med Chem, 60 (2017) 5791-5799.

(32) J. Lu, S. Patel, N. Sharma, S.M. Soisson, R. Kishii, M. Takei, Y. Fukuda, K.J. Lumb, S.B. Singh, Structures of Kibdelomycin Bound to Staphylococcus Aureus Gyrb and Pare Showed a Novel U-Shaped Binding Mode. ACS Chem Biol, 9 (2014) 2023.

(33) B.A. Sherer, K. Hull, O. Green, G. Basarab, S. Hauck, P. Hill, J.T. Loch, G. Mullen, S. Bist, J. Bryant, A. Boriack-Sjodin, J. Read, N. Degrace, M. Uria-Nickelsen, R.N. Illingworth, A.E. Eakin, Pyrrolamide DNA gyrase inhibitors: Optimization of antibacterial activity and efficacy. Bioorg Med Chem Lett, 21 (2011) 7416-7420

(34) M.F. Richter, B.S. Drown, A.P. Riley, A. Garcia, T. Shirai, R.L. Svec, P.J. Hergenrother, Predictive rules for compound accumulation yield a broad-spectrum antibiotic. Nature, 545(7654) (2017) 299-304.

(35) J. Vergalli, I. V. Bodrenko, M. Masi, L. Moynié, S. AcostaGutiérrez, J. H .Naismith, A. Davin-Regli, M. Ceccarelli, B. van den Berg, M. Winterhalter, J. M. Pagès, Porins and smallmolecule translocation across the outer membrane of Gramnegative bacteria. Nat Rev Microbiol, 18(3), (2020) 164-176.

(36) M. Winterhalter, M. Ceccarelli Physical methods to quantify small antibiotic molecules uptake into Gram-negative bacteria. Eur J Pharm Biopharm. 95 (2015) 63-7.

(37) J. Vergalli, E. Dumont, J. Pajović, B. Cinquin, L. Maigre, M. Masi, M. Réfrégiers, J.M. Pagés. Spectrofluorimetric quantification of antibiotic drug concentration in bacterial cells for the characterization of translocation across bacterial membranes. Nat Protoc. 13(6) (2018) 1348-1361.
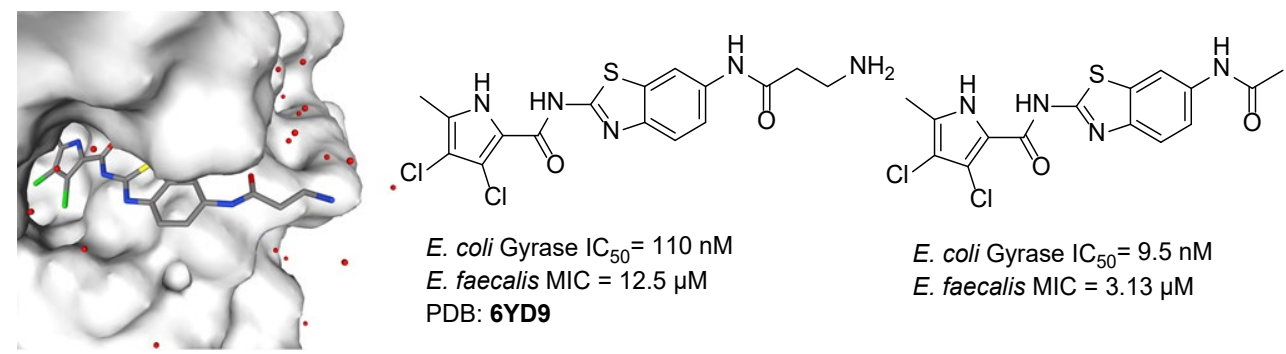

E. coli Gyrase $\mathrm{IC}_{50}=110 \mathrm{nM}$

E. faecalis $\mathrm{MIC}=12.5 \mu \mathrm{M}$ PDB: 6YD9

E. coli Gyrase $\mathrm{IC}_{50}=9.5 \mathrm{nM}$

E. faecalis $\mathrm{MIC}=3.13 \mu \mathrm{M}$ 